\title{
True cost accounting in agri-food networks: a German case study on informational campaigning and responsible implementation
}

\author{
A. Michalke ${ }^{1}$ (D) L. Stein ${ }^{1} \cdot$ R. Fichtner ${ }^{1} \cdot$ T. Gaugler $^{1,2} \cdot$ S. Stoll-Kleemann ${ }^{1}$ \\ Received: 28 August 2021 / Accepted: 25 January 2022 / Published online: 25 February 2022 \\ (c) The Author(s) 2022
}

\begin{abstract}
There is broad scientific consensus that current food systems are neither sustainable nor resilient: many agricultural practices are very resource-intensive and responsible for a large share of global emissions and loss of biodiversity. Consequently, current systems put large pressure on planetary boundaries. According to economic theory, food prices form when there is a balance between supply and demand. Yet, due to the neglect of negative external effects, effective prices are often far from representing the 'true costs'. Current studies show that especially animal-based foodstuff entails vast external costs that currently stay unaccounted for in market prices. Against this background, we explore how informational campaigning on agricultural externalities can contribute to consumer awareness and tolerance of this matter. Further, we investigate the socially just design of monetary incentives and their implementation potentials and challenges. This study builds on the informational campaign of a German supermarket displaying products with two price tags: one of the current market price and the other displaying the 'true' price, which includes several environmental externalities calculated with True Cost Accounting (TCA). Based on interpretations of a consumer survey and a number of expert interviews, in this article we approach the potentials and obstacles of TCA as a communication tool and the challenges of its factual implementation in agri-food networks. Our results show that consumers are generally interested in the topic of true food pricing and would to a certain extent be willing to pay 'true prices' of the inquired foods. However, insufficient transparency and unjust distribution of wealth are feared to bring about communication and social justice concerns in the implementation of TCA. When introducing TCA into current discourse, it is therefore important to develop measures that are socially cautious and backed by relevant legal framework conditions. This poses the chance to create a fair playing ('polluter pays') with a clear assignment of responsibilities to policy makers, and practitioners in addition to customers.
\end{abstract}

Keywords True Cost Accounting (TCA) - Agri-food networks · Sustainable production and consumption · Food policy · Dietary behavior $\cdot$ Food labeling

Handled by Markus Keck, University of Augsburg, Germany

A. Michalke

amelie.michalke@uni-greifswald.de

1 Chair of Sustainability Science and Applied Geography, University of Greifswald, Greifswald, Germany

2 Faculty for Business Administration, Technical University Nuremberg, Nuremberg, Germany

\section{Introduction}

Established agri-food networks are known to have great potential for increasing their inherent sustainability: ecological damages (like greenhouse gas emissions and telecoupled land-use change) and social issues are putting a strain on the environment and the global community (Campbell et al. 2017). Studies show that current food production exceeds planetary boundaries in the present and future. Presently the agri-food sector constitutes about one-quarter of global emissions (Conijn et al. 2018; Benton et al. 2021; IPCC 2019; Gaugler et al. 2020). However, with a meaningful transformation and combination of measures directed 
towards both production and consumption patterns, agriculture would be able to sustainably feed the global population (Gerten et al. 2020; Springmann et al. 2018; Kennedy et al. 2021).

There has been scientific engagement in manifold approaches, which are not mutually exclusive and should be combined when aiming to transform agri-food networks. One prominent example being quantitative governance measures like cap-and-trade of livestock-related greenhouse gasses (Weishaupt et al. 2020). The rather novel approach of True Cost Accounting (TCA) is another possible measure (Kennedy et al. 2021) and is in accordance with the UN Sustainable Development goals as it describes the Polluter Pays Principle (OECD 1975, UN 2015). Current environmental strains and their associated costs are not accounted for within the market prices of food. Rather, they are paid for by society as a whole, for example with rising prices for clean water (Barraque 2003) or damage done to property through severe weather events (CRED 2019; WRI 2020; IPCC 2019). This represents negative externalities of food production and poses market distortions. When engaging the economic instrument of TCA, ecological and sometimes social implications from agricultural production are monetized and internalized into the price of foods.

Foodstuffs' environmental footprint varies tremendously between different categories of food (Poore and Nemecek 2018). TCA approaches are very sensible when aiming at a calculation of external costs for different kinds of individual foodstuff. This gives consumers and producers the chance to understand the variation in environmental damage from products more deeply and could financially incentivize consumption of sustainable diets, as the inherent external costs of more sustainable production is lower (Gemmill-Herren et al. 2021).

The TCA approach employs the economic thesis that modified price levels on behalf of sustainability actuate consumption behavior change: products that cause high damages would be priced proportionally higher than products that are less harmful; consumers act in their best economic interest and would opt for alternatives with lower associated externalities (Pieper et al. 2020). There previously has been some scientific engagement in the topic of TCA within the assessment of foodstuff. Sandhu et al. (2021), for example, present a framework for a TCA along with farm sustainability metrics. Pieper et al. (2020) calculate external climate costs of different foods while Michalke et al. (2021) assess true food costs based on full life cycle analyses (LCA). Hentschl et al. (2021) specifically look at associated climate and biodiversity costs from land-use change caused by animal-based products. Scientists have recently posed accounting for externalities as one major approach to tackle the biodiversity and climate crisis (Bradshaw et al. 2021) and major organizations, like the Rockefeller Foundation, are engaging in this scientific discourse (Gemmill-Herren et al. 2021). Evidently, a focus on the calculation of such costs is identifiable in current TCA-related research. However, the consideration of consumers when aiming to implement such pricing tools into the market is deficient.

A successful and socially responsible realization of TCA needs to be cognizant of existing inequalities and has to go hand in hand with transparently communicating the underlying issues to consumers, as consumption behavior is a personally and culturally sensitive topic (Stoll-Kleemann and Schmidt 2017; Benka-Coker et al. 2018). Besides the paramount influence of socio-economic and political capabilities, it is important to recognize the effect of individual and socio-cultural factors (Kollmuss and Agyeman 2002) such as awareness, knowledge (Bilharz 2000), values, and attitudes (Schwartz 1977).

Especially today, consumption behavior is closely related to a person's lifestyle and their notion of individual freedom (Kelly et al. 2013; Bobić et al. 2012; Grunert et al. 2001; Pribis et al. 2010). Therefore, awareness for ecological damage in foodstuff production must be fostered in order to achieve a willingness to change consumption patterns (Stoll-Kleemann and O'Riordan 2015; Stoll-Kleemann and Schmidt 2017; Malek et al. 2019) or achieve acceptance to pay for the true prices of food (Yormirzoev et al. 2021). Besides producers and consumers, the realm of globally spun networks, such as agriculture and food systems, is of course also significantly influenced by political actors (HeinrichBöll-Foundation 2019; Droste et al. 2016). Their legislation can be either conducive or obstructive to the introduction of TCA. Hence, identifying responsibilities for implementation by all stakeholders, policy makers, practitioners, and consumers alike, seems valuable for a successful integration of TCA, which is renowned as an auspicious instrument to sustainably transform current global food markets (Springmann et al. 2017). It will most definitely not solve all issues arising from agricultural production, but nevertheless, it is a purpose-built tool to transparently communicate and ultimately combat current market imperfections at the intersection of planetary health, lifestyle choices of individuals, and world economics.

TCA implementation is dispersed globally. Within regions of the Global South, the topic is primarily being promoted at farm level or through cooperatives rather than with standardized economic frameworks. Within the European context, heterogeneities in development persist as well: while the Netherlands is considered a TCA frontrunner with plenty of initiatives and pilot projects, German networks are still regionally or topically limited and have the potential for growth. To bring this sustainability endeavor to the attention of German political decision-makers and consumers alike, a German supermarket chain started an informational campaign displaying second price tags based 
on TCA calculations from Michalke et al. (2020) in its store 'Grüner Weg' ('Green Way') in Berlin. Besides the normal market price, some products were also labeled with their 'true prices'. The campaign is meant to purely inform customers about the hidden ecological costs of food, rather than to implement TCA as an economic instrument (cf. Sect. 2.2).

On the basis of the 'True Prices' campaign, this paper analyzes the consumers' knowledge of external costs of foodstuff and the campaign's potential for broadening it. Further, the campaign's design-related flaws, as well as underlying methodological obstacles, are explored. Customers' potential behavioral change after a hypothetical implementation of TCA is also addressed. Finally, we explore different stakeholders' responsibility for, and social issues connected with, an actual implementation of TCA in the foodstuff sector. Answering these questions is pursued with a customer survey (cf. 2.3) and expert interviews (cf. 2.4). This work aims to identify obstacles and potentials for introducing TCA of food as an informational tool, calculation framework, and as an actual economic intervention to consumers, practice, and policies.

\section{Methods and materials}

In the following, we will first elaborate on the study's design and research procedure. We will then explain the 'True Prices' campaign, which the subsequently described consumer survey assesses and the expert interviews are based upon.

\section{Framework}

Figure 1 illustrates the framework design we follow in this study. The scientific background of Michalke et al. (2020) and its application in the 'True Prices' campaign build the foundation for this case study. First, a description of the employed method to calculate ecological costs of foodstuff can be found in Sect. 2.2. Results of this calculation were used to present 'true price' tags (cf. Fig. 1) in the market and showcase more information on the context of ecological costs of foods. On the basis of the 'True Prices' campaign, we conducted quantitative research on the consumers' perception of TCA, and experts' evaluations of TCA research and measures. The face-to-face consumer survey is described in 2.3, the expert interviews, which build the background of our qualitative assessments, are described in 2.4. The respective results are presented in Sect. 3, with Sets. 3.1-3.4 mainly focusing on the quantitative assessments with selective augmentation through the experts' assertions, which are then emphasized in Sect. 3.5. Conclusions for the politically successful and socially compatible implementation of further TCA campaigns can be drawn from the combination of both perspectives (cf. 4 and 5).

\section{'True Prices' campaign}

The following section introduces the informational campaign which uses 'true price tags' to emphasize the context of ecological damages in food production and (in case of their internalization) its effects on the products' prices.

In this paper, the term 'true price / cost' is and will be used according to the calculations by Michalke et al. (2020) and the resulting campaign. However, we want to emphasize that their calculation does not aim to reflect the full extent of all existing social and environmental externalities. For one, the basis for monetary evaluation is currently limited to selected ecological parameters, and most approaches entirely neglect the calculation of social costs. This is due to a lack of data availability and highly complex issues underlying most social externalities. Furthermore, it is important to acknowledge the general limitations of economically assessing complex, non-human systems: valuation will always be instrumental (ethically subjective, anthropocentric) and thus partial (Ekardt 2015; Hansjürgens 2015). Therefore, some scholars argue that in its worst manifestation, TCA is not an all around cure to transform current agricultural market structures but plays into prevailing neo-liberalism by merely 'green coloring' i.e monetarily valuing nature or social justice in a way that uphold the same structures that have caused and are causing environmental and social damage in the first place (Patel 2021; de Adelhart Toorop 2021). Nonetheless, other TCA practitioners and scholars argue that, in light of the factual devaluation taking place, the economisation of (ecological) damage is not only admissible but can provide-if pragmatically assessed and intelligently applied-valuable means for communication and comparability (TEEB 2018; Pieper et al. 2020; Baker et al. 2020; Bradshaw et al. 2021).

Michalke et al. (2020) assess environmental externalities of eight different foods (apples, potatoes, tomatoes, bananas, mozzarella cheese, gouda cheese, milk, and mixed minced meat) based on data from the Federal Environmental Agency of Germany (UBA 2020). The damages included in the assessment are costs from greenhouse gas (GHG) emissions, reactive nitrogen $\left(\mathrm{N}_{\mathrm{r}}\right)$ emissions, energy consumption, and GHG emissions related to land-use change (LUC). These externalities are only parts of the full 'true costs' caused by agricultural practices. Other environmental issues related to food production are, for example, the use of pesticides or water use. Further, social issues related to agricultural production are barely scratched within the context of landuse change (and with it the imposed threat to the human habitat of mostly indigenous peoples) and remain mostly unassessed. 
Fig. 1 Framework design with quantitative and qualitative empirical research based on the 'True Prices' campaign elaborated in Michalke et al. (2020)

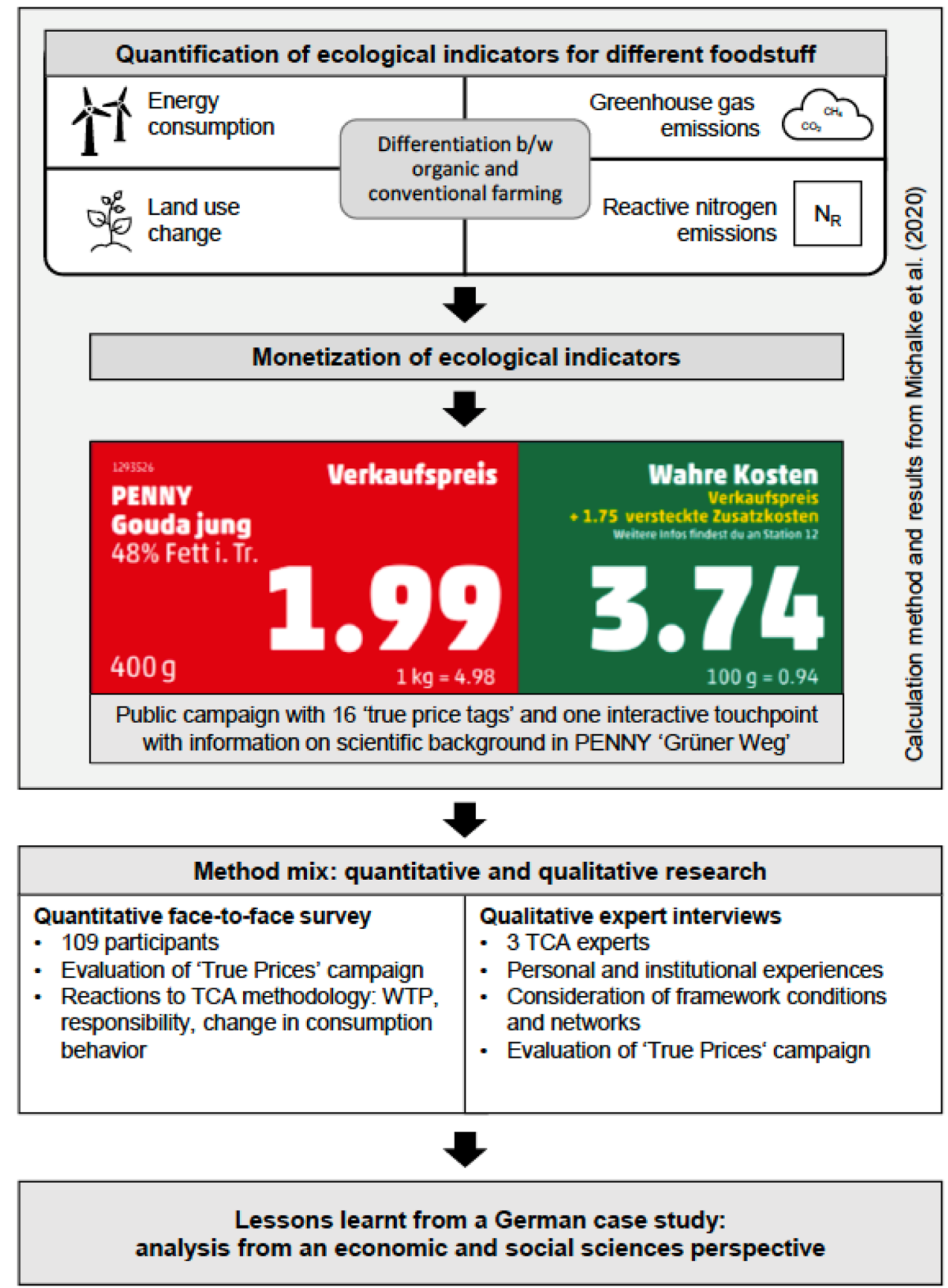

Within the assessment of Michalke et al. (2020), a differentiation was made between different foods as well as between distinct production practices. Each product was assessed when produced under conventional and organic conditions. Under different regulations and conditions, production inputs will vary. For example, in organic production artificial nitrogen fertilizer is only allowed to a very limited extent (European Union 2008), which impacts nitrogen emissions released during the production process. The differentiation was made based on a literature analysis of studies comparing the two production practices. The system boundaries are defined as cradle-to-gate, meaning that all pre-production (like production of fertilizers, feed, seeds, etc.), production at the farm stage, as well as processing after the farm stage were included in the externality assessment. Emissions occurring in the supermarket, during transport to, or through processing in the home of consumers are not included. The monetization of damages was based on data from cost-benefit-analyses from the Federal Environmental Agency (for GHG and energy consumption; UBA 2019) and the European Nitrogen Assessment (for $\mathrm{N}_{\mathrm{r}}$; Sutton et al. 2011). 
Table 1 External costs from GHG and $\mathrm{N}_{\mathrm{r}}$ emissions, energy consumption, and LUC related GHG emissions from Michalke et al. (2020)

\begin{tabular}{|c|c|c|}
\hline Product & Organic $[€ / \mathrm{kg}$ product $]$ & $\begin{array}{l}\text { Conventional [ } € \\
/ \mathrm{kg} \text { product] }\end{array}$ \\
\hline Apple & 0.12 & 0.17 \\
\hline Tomato & 0.20 & 0.18 \\
\hline Potato & 0.07 & 0.07 \\
\hline Banana & 0.15 & 0.20 \\
\hline Mozzarella & 2.14 & 2.84 \\
\hline Gouda & 3.26 & 4.38 \\
\hline Milk & 0.75 & 0.89 \\
\hline Minced meat ${ }^{a}$ & 11.58 & 9.67 \\
\hline
\end{tabular}

Costs are presented per $\mathrm{kg}$ of product. These costs do not include the current market price, but solely reflect external costs.

${ }^{a}$ The minced meat consists of a mix between pork and beef as commonly sold in German supermarkets. In the text, we refer to it as minced meat.

External costs were calculated with the described methods and data for every product mentioned. These costs (cf. Table 1) were then added to the current market prices by the supermarket operators themselves: price tags were printed with not only the market prices at which products are sold presently but also with the 'true prices' as calculated by Michalke et al. (2020). These price tags were used for informational purposes only. This was because customers were not actually able to pay for the 'true prices' at checkout. There is also the possibility in store to find out more about the context of agricultural externalities via an interactive information point where customers can, for example, guess the 'true costs' of a certain product.

\section{Quantitative survey}

As aforementioned, the TCA calculations by Michalke et al. (2020; cf. 2.2) were used in a supermarket informational campaign in a German discounter in Berlin. The survey's main focus is to evaluate this campaign, and with it the participants' general knowledge of ecological costs caused by the agri-food industry. Further, we aimed to obtain an estimate of the general societal attitude and expectations towards TCA and its implementation.

A quantitative face-to-face survey of medium length (duration 7-10 min) was designed (Stocké 2014). The standardized questionnaire (Reinecke 2014) was carried out via the tool SoSci Survey. SPSS was used for the statistical analysis of the collected data. The survey was divided into different sections. First, consumers were asked about their general purchasing behavior and their familiarity with the campaign. Only after such first questions did the interviewers explain the background of the campaign to participants. They were then asked for their perception of the campaign as well as their willingness to pay for the 'true prices' of different products. Furthermore, information was collected on which factors of ecological or social impact should be internalized in true pricing and whom of government, economic sector, or general public the respondents deem responsible for initiating TCA. Assuming TCA would be implemented, consumers were questioned on whether they would change their consumption intake regarding organic and animal-based products. Finally, selected socio-demographic data of participants was collected to evaluate the composition of the sample.

The collected sociodemographic data regarding age, household, and budget for grocery presented in the sample (109 participants) to be fairly representative for German society as a whole (cf. Table 2$) .66 \%$ female $(N=72)$ and $34 \%(N=37)$ male customers participated in the survey. Gender-specific differences in grocery purchase behavior and pro-environmental behavior, in general, are often discussed (Bandura et al. 1996; Borden and Francis 1978; Dietz et al. 2002). However, in this particular survey, we focused on households as a unit and, therefore, genderspecific conclusions are inadmissible.

Table 2 Structure of survey participants

\begin{tabular}{lll}
\hline & $\begin{array}{l}\text { Survey participants } \\
(n=109)\end{array}$ & $\begin{array}{l}\text { German } \\
\text { population } \\
\text { (average) }\end{array}$ \\
\hline Age [years] & & \\
Mean & 45.05 & $46.51^{\mathrm{a}}$ \\
Min & 14 & $\mathrm{n} / \mathrm{a}$ \\
Max & 86 & $\mathrm{n} / \mathrm{a}$ \\
Gender [\%] & & \\
Female & 66 & $50.7^{\mathrm{b}}$ \\
Male & 34 & $49.3^{\mathrm{b}}$ \\
Household size [persons/ & \\
household] & & \\
Mean & 2.29 & $2.03^{\mathrm{c}}$ \\
Min & 1 & $\mathrm{n} / \mathrm{a}$ \\
Max & 8 & $\mathrm{n} / \mathrm{a}$ \\
Monthly budget grocery & & \\
[€/household] & & $321^{\mathrm{d}}$ \\
Mean & 360.64 & $\mathrm{n} / \mathrm{a}$ \\
Min & 15 & $\mathrm{n} / \mathrm{a}$ \\
Max & 1500 & \\
\hline
\end{tabular}

${ }^{\mathrm{a}}$ Federal Institute for Population Research (2019)

${ }^{\mathrm{b}}$ Federal Statistical Office (2021a)

${ }^{\mathrm{c}}$ Federal Statistical Office (2021b)

${ }^{\mathrm{d}}$ Federal Statistical Office (2021c) 


\section{Qualitative interviews}

Following the quantitative survey and campaign evaluation, three expert interviews with TCA practitioners were conducted. These interviews were executed to validate and complement perceptions and ideas of consumers. Further, the interviewees were encouraged to share their expertise on potentials and obstacles for introducing TCA approaches today and in the future.

These interviews followed a predesigned interview guideline with the possibility for further ad-hoc questions and discussion (Baur and Blasius 2014) and were evaluated according to the rules of qualitative content analysis (Mayring and Fenzl 2014). Topical sections were, first, the experts' business involvement in TCA and their perception of acceptance and interest on the market, putting a focus on their personal and institutional experiences. Afterwards, they were asked about chances and risks regarding the implementation of TCA with regard to the political and administrative environment. Finally, their assessment of the 'True Prices' campaign and selected takeaways from the consumer survey were discussed. The three interviews took approximately $60 \mathrm{~min}$ each and were conducted via recorded video call. For analysis, video-cued thought protocols were engaged, and important excerpts were summarized.

Experts from three different TCA perspectives were consulted for the research. The first interview partner was a representative of 'Eosta' (abbreviated to "EO" in the following). Eosta is committed to the implementation of TCA and acts as a global distributor specializing in organic fruit and vegetables with a focus on greenhouse cultivation and overseas fruits. A representative of 'Truesday' (abbreviated to "TD" in the following), a TCA specialty coffee brand residing in Berlin, which is selling the first German true price coffee, was selected as the second expert. A TCA consultant with 'Soil \& More Impacts' (abbreviated to "SI" in the following), acted as the third expert. Soil \& More Impacts identifies and monetizes costs and benefits of agriculture with a focus on soil, climate, water, and biodiversity. Their target groups include i.a. the agri-food and financial sectors, policy makers, and consumers.

\section{Results}

We present the results of both the customer survey and experts' evaluation in the following. With these results, we want to specifically focus on the general knowledge of consumers about TCA and the communication of the approach both within the campaign and in general. We further investigate customers' reaction if TCA were to be broadly introduced to the market and the perceived responsibility of different stakeholders for a socially just implementation.

\section{Consumers' knowledge of ecological costs}

In the first part of the survey, we aimed to explore whether customers are generally aware of (ecological) externalities. Out of 109 participants in the standardized face-to-face survey, a total of $56 \%(N=61)$ did notice the price tags and/or the infopoint, which constituted the 'True Prices' informational campaign. Even though over half of the participants did see the price tags, they did not necessarily know their meaning nor were able to explain the price increase and calculation indicators. Only $10.09 \%(N=11)$ were able to name one or several reasons for the increased price [indicated ecological damages, as calculated based on Michalke et al. (2020)]. Additionally, a further $20.18 \%(N=22)$ expected different social factors to be the reason for the price increase displayed by the 'true price' tags. Mentioned factors as such were, for example, animal welfare, fair wages for workers in the production sector, and production costs (however, these aspects were neither included in the calculations nor displayed at the information point in the market).

Regarding the participants' general knowledge of the topic, $77.1 \%(N=84)$ had heard of the true prices of food and its underlying issues before. Most of the participants $(41.3 \%, N=45)$ received the information via media (TV, radio, newspaper). Ten people (9.2\%) actually stated that they were made aware of the existing problems through the 'True Prices' campaign itself. Other sources of information mentioned by respondents were social media $(N=7)$, friends and family $(N=7)$, farmers' lobby $(N=4)$, or climate activist groups $(N=3)$.

These findings on consumers' general perception of the campaign indicate a knowledge gap for ecological costs in foodstuff production and agri-food networks within the sample. The interviewed TCA practitioners agree with a presumed knowledge deficit (SI, EO), stating that while the consumers' interest is promising for a successful and accepted implementation of TCA, their level of knowledge still seems insufficient to motivate extensive changes in consumption behavior (EO, TD).

\section{Campaign communication}

Further, we investigated if informational campaigns, such as the one presented here, can create awareness for ecological issues in current agri-food systems. We were also interested in the campaign's design-related flaws. A majority of $63.3 \%(N=69)$ assessed the campaign and its message as 'good / interesting'. On the other hand, $14.7 \%(N=16)$ rated it as 'pointless / superfluous' or were 'skeptical' (12.8\%, $N=14$ ) about it. Findings from the consumer survey show some potential to increase efforts in presentation, explanation, and structuring for future campaigns. As described in 3.1, participants showed very little basic understanding of 
context, despite the fact that a majority had heard of the topic before, and presumed other issues underlying the 'true prices' than those actually addressed in the campaign. Furthermore, some participants were confused over the color coding of price tags (for reference, cf. Fig. 1) and assumed the price tags' green part to signify organic produce $(2.75 \%$, $\mathrm{N}=3$ ), and/or the red part to display a product on discount $(8.25 \%, \mathrm{~N}=9)$.

The three experts collectively agree that public campaigns signify great potential towards raising awareness for negative externalities as they utilize TCA as a method to transparently communicate ecological damage to the general public. The Eosta representative (EO) highlights the need for a mindshift and raised levels of awareness of the current unsustainability in agri-food networks as fundamental to introducing TCA as an accepted accounting practice. Truesday Coffee (TD) suggests complementation knowledge-focused measures with tangible offers to take immediate action. This ties in with the statements of two participants who suggested that consumers should indeed have the opportunity to pay the true price voluntarily. TCAs methodological strength lies in addressing these crucial challenges through the holistic integration of people and planet, and thus holds great potential in improving the currently unsustainable agri-food networks (SI, EO, TD).

\section{Monetary factors influencing consumption behavior}

Regarding TCAs influence on consumers' behavior, we focused on estimating the customers' willingness to pay for 'true prices' and how the implementation of TCA adjusted pricing would possibly change consumption habits. Assuming that an implementation of the TCA methodology will raise food prices, participants were asked about their willingness to pay (WTP) for product prices with internalized ecological costs. WTP is defined as the maximum price at or below which a customer will definitely buy a product (Tisdell 2005).

To determine the WTP in the survey, three conventionally produced products with their calculated true cost price tag were presented to the customers. Different product categories were included, one plant-based food item (apples) and two animal products: gouda cheese (dairy) and minced meat. Participants were asked whether they would be willing to pay the corresponding 'true price' for the respective product or, if not, how much they would maximally be willing to pay. The price increases in the Penny supermarket are composed as follows (cf. Table 1): four medium-sized apples (500 g) entail additional negative externalities of $0.09 €$, one package of gouda cheese $(400 \mathrm{~g})$ comprises a surplus of $1.75 €$, and for $500 \mathrm{~g}$ minced meat an additional cost of $4.83 €$ was determined.

Most respondents $(94.5 \%, N=103)$ were willing to pay the 'true price' for the apples. A little less than half of the participants $(43.9 \%, N=47)$ agreed to pay the 'true price' for the gouda cheese. WTP for minced meat was lowest with $33.7 \%(N=35)$ of participants consenting to cover the surplus entirely. Comparing the three selected products and their WTP data, it is apparent that customers were least willing to pay for the most expensive product (which also includes the highest negative externalities).

Provided the participants rejected paying the 'true price' ('if not'), their maximum WTP was subsequently inquired. This was done to get more detailed answers on socially accepted increases in food prices. As shown in Fig. 2, the maximum WTP for gouda was, in relation to the current market price, higher than for minced meat. On average, those refusing to cover the 'true price' were willing to pay approx. $29 \%$ of the price increase for minced meat, which corresponds to a value of $1.41 €$. For the gouda cheese, the value
Fig. 2 Relative frequencies of given answers to the questions "Would you pay the following price increase for the true cost of these products?". If the previous answer was "no": "What would be your maximum willingness to pay?". $\mathrm{N}=109$

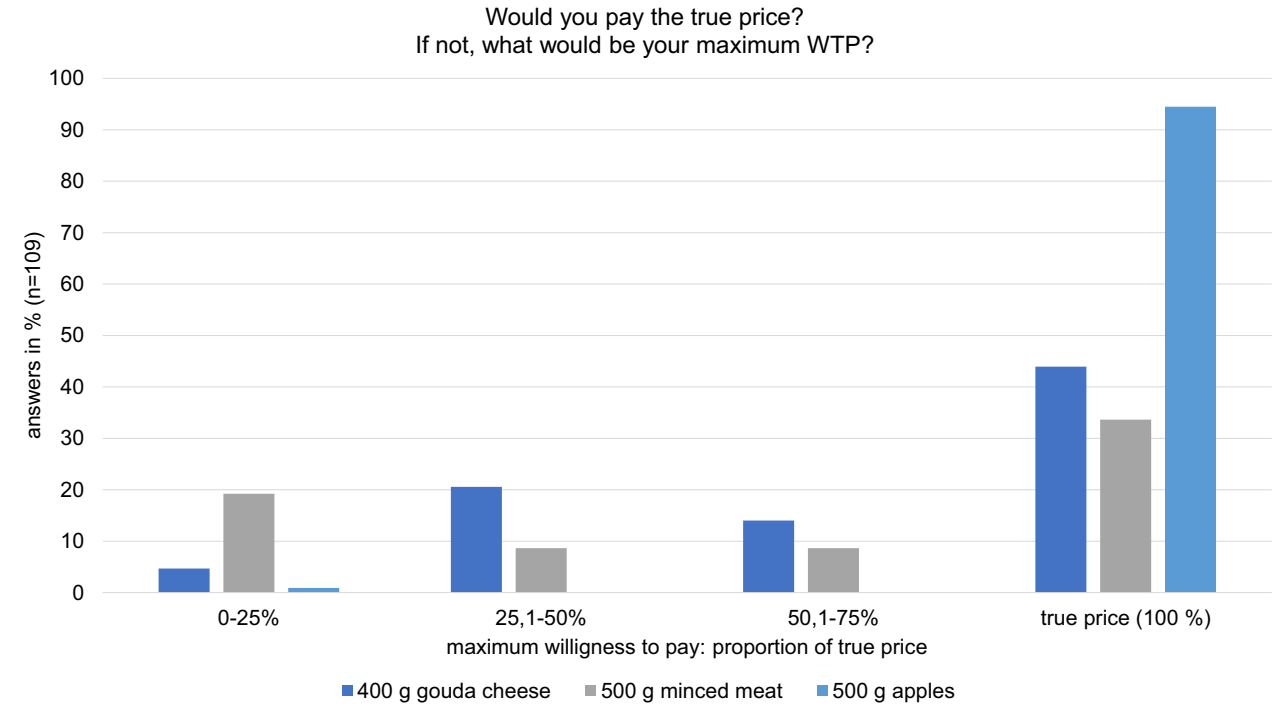


is slightly higher: the participants were on average willing to pay approx. $38 \%$ of the calculated negative externalities. This resembles a monetary value of $0.66 €$. Comparing the collected WTP data, less acceptance for drastic price increases of products can be observed.

Another focus of the study was to explore potential changes in consumption behavior. As described, participants had already been informed about the general methodology of TCA for food and the underlying calculation base (cf. 3.3). Therefore, a general understanding of why prices would be higher with TCA could be attested when inquiring about potential consumption changes. To measure the possible effects of true pricing on consumer behavior, questions focused on changes in consumption of organic and animalbased products.

First, we will give some perspective on the price design of organic and conventional products, respectively. In most cases, the calculated externalities of organic produce are lower than those of conventional produce (except for tomatoes and minced meat, cf. Table 1). Therefore, the price of organic foods would rise less sharply when implementing TCA. As of now, organic products generally have higher market prices than their conventional conspecifics, TCA implementation would diminish these market price differences in favor of organic products; thus making organic products more attractive to consumers not only on an ideological, but also financial basis. Consequently, when consumers were asked if an implementation of TCA for foodstuff would lead them to opt for more organic produce, the following results were yielded: $76.1 \%(N=83)$ of respondents stated that they would increasingly resort to organic products compared to their current shopping behavior. 23\% $(N=25)$ replied they would not buy more organic products than they do now. The answer 'no' was further elaborated in a subsequent open question with the following replies: doubts about the organic label $(64 \%, N=14)$, already a lot of organic products $(18 \%, N=4)$, daily quality more important $(9 \%, N=2)$, brands instead of the organic label $(5 \%, N=1)$, and favor of regional products $(5 \%, N=1)$.

Second, we examined the possibility of behavior change regarding animal products (cf. Fig. 3). Based on the calculations of Michalke et al. (2021), animal-based foods entail significantly higher negative externalities than plant-based products (cf. Table 1). $60.6 \%(N=66)$ of participants stated they would reduce their consumption of animal products if the previously explained true pricing was implemented. People who answered in the negative $(39 \%, N=43)$ gave the following reasons: already reduced consumption compared to previous eating habits $(45 \%, N=17)$, taste preference $(24 \%$, $N=9$ ), (family) eating habits $(15 \%, N=6)$, no present consumption $(8 \%, N=3)$, and ability to pay $(5 \%, N=2)$.

Overall, it can be stated that consumers generally would be willing to change their behavior to a certain extent, if positive or negative monetary incentives were created through the implementation of TCA for food. More than $75 \%(N=83)$ of participants would increase their consumption of organic products in particular. The data from this case study also demonstrates that the consumption of animal products has the potential to be reduced considerably: more than $60 \%(N=66)$ of respondents stated that a comprehensive implementation of 'true prices' would lead them to reduce their consumption of animal-based products.

\section{Responsibility for implementation}

The last focus of the survey was assessing the perceived responsibility for TCA and its modes of implementation to transform currently unsustainable agri-food networks. Here, the consumers' perspective on the importance of TCA in
Fig. 3 Relative answers to the questions "If TCA was generally implemented...": a "... would you then buy more organic products?" and b “... would you then reduce your consumption of animal products?". $N=109$

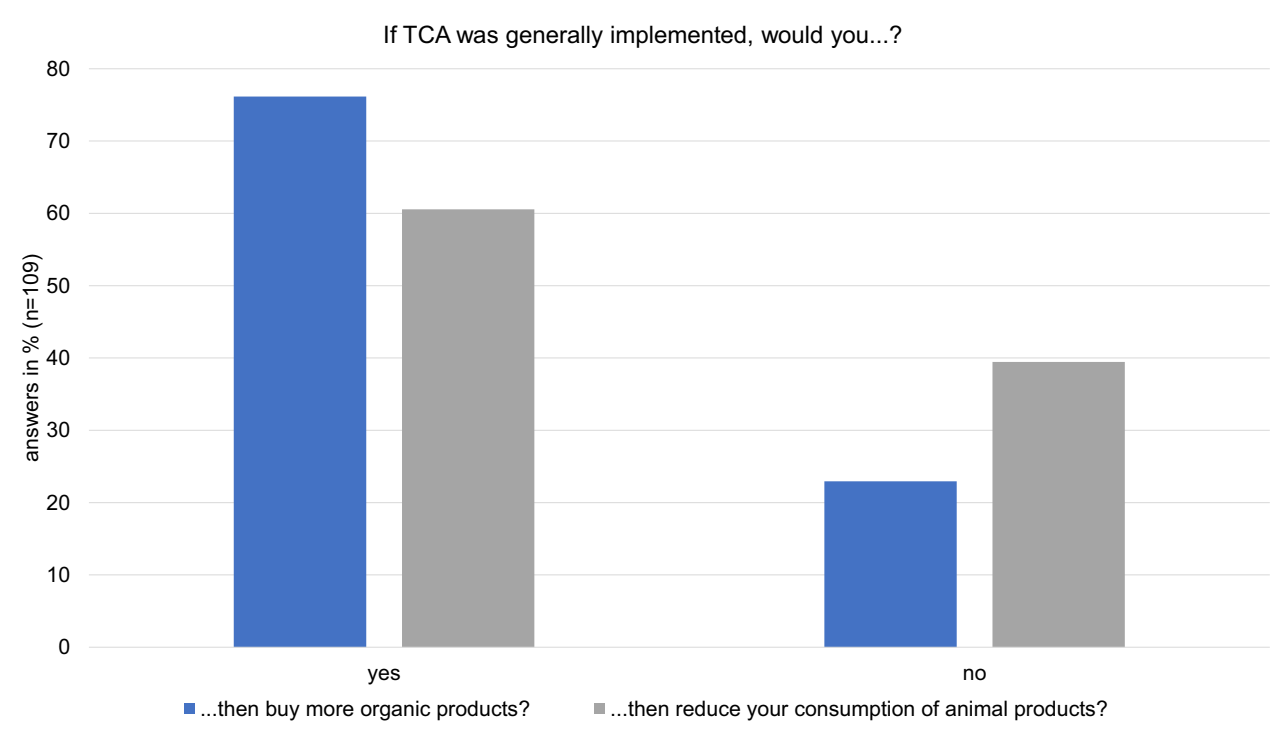


general and stakeholder responsibility for the implementation of 'true prices' was explored.

To attain broad acceptance, it is important to validate which aspects of TCA approaches are especially valued by the general public. Hence, we asked participants $(N=109)$ which of the following factors would be most important to be included in TCA: ecological, social or animal welfare (maximum two selections permitted). Alternatively, the options of 'all of the aforementioned' or 'no increase in market prices' were given. The results reinforce the selfprescribed necessity for holistic assessment in TCA. 69.8\% $(N=64)$ replied that all factors were equally important for consideration. The wish for conceptual inclusivity is further highlighted as both social factors $(20.7 \%, N=19)$ and animal welfare $(30.5 \%, N=28)$ received more single mentions than ecological factors $(16.4 \%, N=15)$. Three people $(3.3 \%)$ opted for 'no price increase' as primarily important.

The general need for TCA is a widely shared view. Amongst the participants $(N=109)$, a large majority of over $90 \%$ ascribed importance to implementing TCA. 51.4\% $(N=56)$ stated this endeavor to be 'very important' a further 41.3\% $(N=45)$ selected the option 'rather important', and only two people (1.8\%) deemed it to be 'not important at all'.

As TCA is a relatively new tool, it is still largely pushed by individual actors and networks (cf. 4). Three mutually inclusive pathways for a transformation of agri-food systems through TCA are possible: motivated by the government through policies, the economic sector through responsible production, and the general public through conscious consumption. Each could potentially be viewed as liable to translate this novel method into the common application. We, therefore, asked the participants $(N=107)$ which of the three actors they deem responsible. They were asked to rank the government, economic sector, and general public in terms of their perceived duty to implement sustainable food production and consumption practices. At least one rank had to be selected. Alternatively, they could opt for "all actors equally responsible".

As seen in Fig. 4, the majority of participants (54.2\%; $N=58$ ) view the government, or policy makers, as foremost responsible in implementing more sustainable practices into agri-food networks (rank 1). Another 18.7\% $(N=20)$ voted for the option 'all actors equally'. The general public was voted foremost in charge by $17.8 \%(N=19)$, while the economic sector received $9.4 \%(N=10)$ of votes. The latter was, however, most often defined as second rank responsible with $21.5 \%(N=23)$. To get an overview, overall mentions of each actor are interesting as well. While the government was by far the most mentioned $(N=72)$ over all ranks, the general public came second $(N=50)$, and the economic sector was in third place $(N=44)$. This indicates that consumers do see the necessity of policy makers to act according to current needs for sustainability.

\section{Pathways for implementation}

Throughout the survey, questions regarding responsibility for implementation and ways of implementation arose which are addressed here. In the qualitative expert interviews, key challenges that await clarification prior to a successful application of TCA were of interest. Furthermore, we inquired what would be effective means, incentives, and framework conditions to successfully engage TCA in practice.

To realize the potential inherent to TCA approaches abundant methodological finetuning is needed (SI, TD). To remove obstacles regarding customer approval and comparability, it is important to anticipate critical feedback prior to introducing the method as a general intervention to markets, claims Soil \& More Impacts, explaining that TCA needs to meet the self-prescribed demand of holistic assessment
Fig. 4 Relative frequencies of given answers to the question "Whom do you see responsible to act?". $N=107$

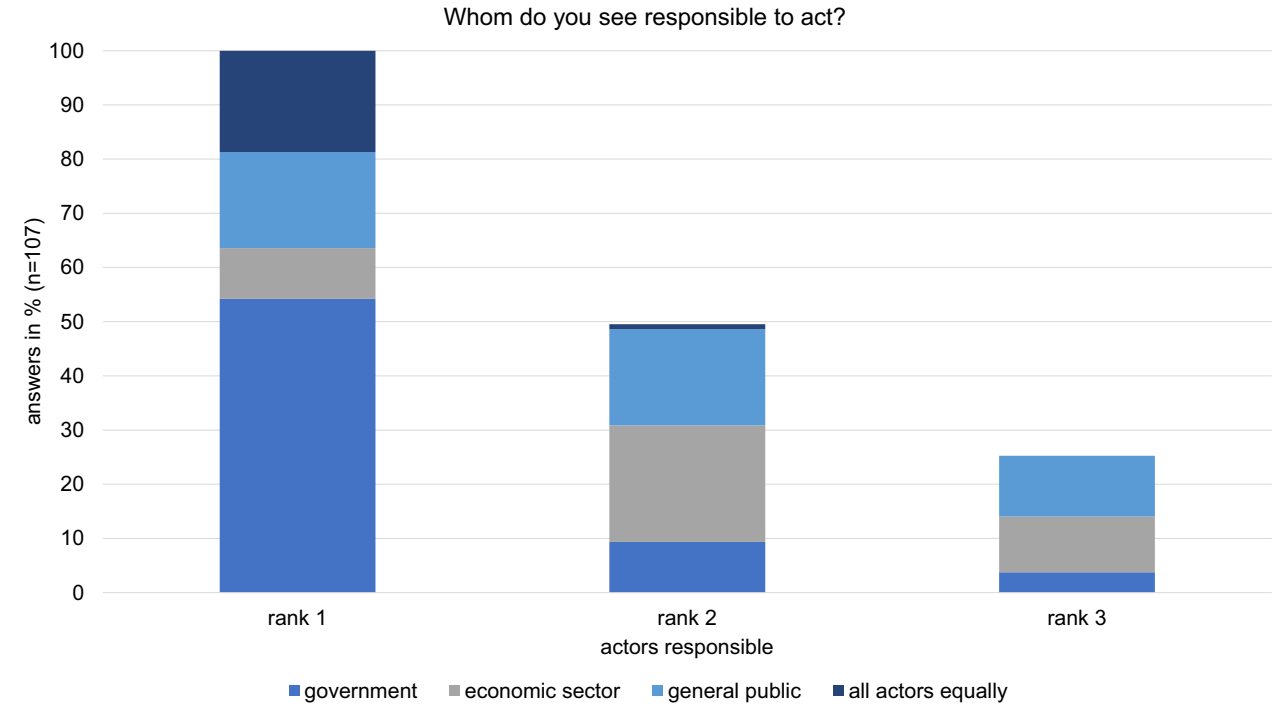


across all forms of capital. Fields for further refinement are general preciseness and the calculation of animal-based products which still prove to be problematic in confident calculations (SI). Specificities in production practices, such as distinctly accounting for certified products (e.g., organic, fairtrade), need further development (TD, EO), and with respect to a persisting lack of consumers' trust and knowledge, proper communicating is needed (cf. 3.1).

A clear scientific consensus for a uniform approach moving forward is yet to be reached (cf. 4.1). As of now, existing TCA methods fall short of aspired levels of holistic accounting but are foreseen to be adequately developed to meet the level of accuracy required for proper transparency (SI, TD). Although it remains challenging to combine planetary and societal sustainability with existing data gaps, this is perceived as a clear strength of TCA: approaches exceed interventions with a singular focus on climate and emissions by integrating diverse ecological indicators, e.g., as addressed in the Planetary Boundaries framework (SI, EO).

To realize the full potential inherent to TCA, a sensible integration of social and ecological dimensions, and herein entailed sensitive data differences needs to be accomplished (EO, SI,TD). One fundamental question yet to be clarified is considering the technical approach to compare and possibly offset natural, human, and social capital (SI). There are manifold approaches to do this (e.g. secondary or primary data approach) and a standardization is not yet underway, which would arguably be beneficial for the consumers' acceptance. Literature also shows that whichever approach is used for the calculation of true prices, it needs to be comprehensible and transparent for the target group the respective calculation is aimed at (Gemmill-Herren et al. 2021).

While discussing the further pathways for implementation of TCA across all stakeholders (public society, government, and economy), Truesday suggests a TCA label as an adequate step towards improving TCA standards and reputation, while Soil \& More Impacts reiterates the central importance of engaging the Polluter Pays Principle: Hastily introducing a TCA label could insufficiently place the customer into the main focus of being responsible for implementation, whilst diminishing the producing actors' role in achieving higher levels of sustainability in agri-food networks. This ties with concerns of TCA measures adding to social injustice while failing to combat the prevailing market distortions in true ecological and social pricing, which are to be tackled by policy makers alike.

In the interviews, experts focused on the productive potential of political action ahead: TCA's imminent strength in holistically integrating societal and planetary issues suitably addresses the sustainability endeavors that global politics claim to strive towards (SI, TD, EO). Hence, an extensive implementation of TCA pursued by the legislature of all states (at least in the Global North) seems to be the logical step forward. A number of established instruments and frameworks exist (such as subsidiary practice, $\mathrm{CO}_{2}$-Pricing, and taxation) that would profit from employing TCA, as elaborated by the experts. Such integration of true pricing pre-consumer stage seems favorable with respect to social implications and general leverage for systemic transformation.

Crucial traits for successful development are listed as follows: an active exchange between all players, administrative support, public promotion, and ultimately a formalization of TCA structures. Outside reactions to TCA on business levels vary greatly, all experts agree. TCA is already viewed as a veritable assessment tool for transparency in supply chains, communication, and comparison. On the corporate side, TCA seems to be gaining increased standing, as the food industry recognizes the need for a uniform measurement tool regarding ecological costs (SI). While more and more companies understand TCA as a possibility for profit through frontrunning and thus show interest in engaging in these contexts through adapting their business approaches regarding socio-ecological responsibilities, other players on the market view TCA with skepticism and behave in a waitand-see manner (SI, TD, EO).

The experts highlight the inherent theory of change: through monetization, TCA is 'speaking the language' of financial markets. By internalizing all costs (social, ecological) into the definition of profit it poses a powerful tool to realize the Polluter Pays Principle. Thus, TCA would help to create a fair playing field for all economic actors (EO, SI). Soil \& More Impacts explains a double advantage for commercial actors in the agri-food sector: with increasing legal requirements, TCA calculations will not continue to be an immense additional effort but will become less expensive and, at the same time, provide a clear competitive advantage in a world focusing increasingly on socio-ecological justice in economic undertakings. Truesday Coffee emphasizes the scientific data basis particularly, as sufficient availability of such enables a fair and less hierarchical relation between all players in the globally-spun agri-food networks. Latest developments in the German and European financial sector (e.g., the NFRD, parameters considered by rating agencies, etc.) complement TCA approaches (EO, SI). While Soil \& More Impacts highlights its quality as a tool for risk minimization for businesses and companies, Eosta sees potential for a new, inclusive profit definition, in which social and ecological capital is inherent (SI). Nevertheless, it remains unclear whether a sufficient number of businesses can find the selfmotivated courage to follow TCA standards to sustainably transform agri-food networks. Therefore, and as mirrored in the survey (cf. 3.4), governmental actors are perceived as responsible in guiding the implementation of TCA.

The importance of conclusive governance involvement in the implementation of TCA measures becomes especially 
apparent with regard to the possibility of TCA increasing the unjust distribution of wealth. On that account, social justice in its manifold expressions needs special addressing: while TCA methods strive for a fair distribution of wealth along global supply chains (e.g., in the form of living wages), it is also important to focus on persistent and rising distributionrelated injustice within European (German) society (EO, SI, TD). To view and utilize TCA as a tool to analyze and adapt market distortions within the supply chains (pre consumer) is paramount (SI). Solely marketing eco-friendly diets or adding the previously externalized costs onto the final consumer price is considered insufficient as it counteracts the Polluter Pays Principle (SI). At the same time, certain consumer prices (for environmentally strenuous products) are likely to ascend (cf. Table 1), raising the issue of citizens' ability to pay for eventually higher food prices, especially for marginalized or underprivileged groups (TD). This ties in with several informal statements given in the consumer survey, where participants argued their income would not suffice for paying the true prices, especially for products that are already of higher cost levels. Questioned consumers also did state the price as the most important factor, when shopping for groceries $(36.7 \%, N=40)$, implying a vulnerability towards rising prices at least in the examined sample.

\section{Discussion}

In our discussion, we will highlight points of interest that arise when critically assessing TCA methods, as well as discussing the responsibility for, and social justice issues arising with an implementation of TCA. The section closes with a summary of the potentials and challenges of TCA (cf. Table 3).

\section{Methodological development}

Through the medium of damage calculation and its subsequent monetization, and thereby achieved levels of transparency, TCA is helping agri-food players and the general public to make socio-ecologically just decisions (GemmillHerren et al. 2021). However, Eosta emphasizes that TCA is not a 'silver bullet' for a sustainable transformation in the agri-food sector. Amongst the experts and TCA actors, diverse views exist on the question whether a common TCA standard, as well as establishing a common TCA label, is a feasible and advisable step forward for the short-term future. A standardized approach in TCA is regarded as important prior to general implementation to make results comparable and increase the involvement of both practitioners and consumers (Baker et al. 2020; de Adelhart Toorop et al. 2021). Standardization also avoids shortcomings in the economic application, as varying TCA approaches (and resulting calculated costs) will likely lead the market to adopt 'the least expensive', less holistic or progressive approach (SI).

Table 3 Potentials and Challenges of TCA implementation

TCA: holistic tool considering multifaceted ecological services (and social impacts)

\begin{tabular}{|c|c|}
\hline Potentials & Challenges \\
\hline $\begin{array}{l}\text { communication tool within the financial sector } \\
\text { Conclusive monetization of ecological damages beyond emissions } \\
\text { (planetary boundaries) } \\
\text { Increased transparency regarding supply chains and cash flow }\end{array}$ & $\begin{array}{l}\text { Variability in approaches: further improvement crucial before introduc- } \\
\text { ing TCA as a general intervention } \\
\text { Primary data: may not be feasible for comprehensive implementation } \\
\text { Secondary data: inaccuracy due to generalization in data acquisition }\end{array}$ \\
\hline $\begin{array}{l}\text { Compatible with existing frameworks } \\
\text { Quantifies Polluter Pays Principle: integration of ecological and social } \\
\text { costs into the definition of profit }\end{array}$ & $\begin{array}{l}\text { Lacking pressure (formalization) to realize a socio-ecologically just } \\
\text { accounting for the political, economic, and public sector }\end{array}$ \\
\hline $\begin{array}{l}\text { Risk minimization for businesses, profit maximization through front- } \\
\text { running }\end{array}$ & initial Costs of TCA implementation \\
\hline $\begin{array}{l}\text { Communication and transparency tool for consumer knowledge } \\
\text { Comparability of production processes }\end{array}$ & $\begin{array}{l}\text { risk Of reputation loss and abuse due to different and non-transparent } \\
\text { standards (greenwashing) }\end{array}$ \\
\hline $\begin{array}{l}\text { TCA label: } \\
\text { Consistent global standard } \\
\text { Trustworthiness }\end{array}$ & $\begin{array}{l}\text { TCA label: } \\
\text { No common standard yet } \\
\text { Futility due to label weariness }\end{array}$ \\
\hline $\begin{array}{l}\text { instrument to tackle knowledge-action gap: } \\
\text { Change in consumption behavior towards environmentally friendly } \\
\text { diets (nudging) } \\
\text { Reduction of animal products } \\
\text { Increase in organic products }\end{array}$ & $\begin{array}{l}\text { Increasing social injustice among consumers if implemented insensitive } \\
\text { to economic inequalities and welfare regulations (ability to pay) }\end{array}$ \\
\hline
\end{tabular}


Unclear and differing calculation bases might yield distrust and subsequently less acceptance from consumers and could give way for improper application (i.e. greenwashing) (TD). When using TCA as a communication tool for consumers, the higher accuracy and accompanying complexity the more overwhelmed customers could be with the context. It is, however, pivotal to aim at an assessment, which is as precise as possible, for the use in conservative accounting practice, and to exactly monitor and compare differences in cultivation methods, which is needed to generate change in agricultural practice.

Another problem is seen with the wide range in the economic evaluation of damage: what is the price for clean air or water, a stable climate or biodiverse ecosystems? Not only is an evaluation likely to be subjective-as seen, for example, through the application of the WTP method where a sample is asked how much (e.g. an unchanged ecosystem) is worth to them personally (van Grinsven et al. 2013) but can also be influenced, for example, through the environmental boundaries or goals that underlie the evaluation methods-for instance the increased price for $\mathrm{CO} 2$ equivalents from the UBA's Methodological Convention 2.0 (80€ per t) to 3.0 (180€ per t) (UBA 2012, 2019). Therefore, TCA calculations can be seen as steps in the right direction of integrating arising environmental or social costs into market prices. However, under current methodological advances it cannot represent the reality of the inherent economic damage. One practical resort to minimize such methodological shortcomings could be the conjoined implementation of price-based instruments (such as TCA) and absolute quantity measures (e.g. cap-and-trade schemes; such as presented in Weishaupt et al. 2020) that are aligned with existing declarations of commitment to curb climate change and the manifold ecological crises (e.g. the Paris Agreement) (cf. Rodi 2010).

\section{Implementing TCA: administrative framework and citizens' acceptance}

The governmental tardiness in comprehensive, effective action targeting the climate and global crises is amply known and scientifically discussed (IPCC 2019). The German government and European administrative bodies, like many around the world, have committed themselves to introduce the change necessary for economically viable and socially sustainable agriculture that provides (global) food security (German Federal Government 2021; Heinrich-Böll-Foundation 2019) and thus complies with the United Nations' Sustainable Development Goals (United Nations 2019).

Thus, the general need for TCA seems apparent with regard to current and upcoming policy standards and directives: by integrating ecological (and social) damages into economic measurements, TCA could be the logical instrument to execute novelties in European governmental initiatives (Bradshaw et al. 2021). Nevertheless, in the German Sustainability Strategy, it is written that the sustainable development of agri-food networks "can only succeed if politics, business and consumers assume their respective responsibilities" (German Federal Government 2021, p. 59). This could indicate that governmental structures do not necessarily see the responsibility to act lying primarily with them, thus underestimating their role as a driver of social innovation for transformation (Droste et al. 2016); and contrasts the consumers' opinion voiced in the survey, expressing the necessity of TCA implementation commenced through governmental bodies (cf. 3.4).

To elaborate on the role of general society (both in their consumer and citizen role), EO and SI postulate that the present difference between consumer and citizen needs to be bridged, so that consumption behavior complies with a common societal moral code and ethical foundations represented, i.e. in the Human Rights. This is in accordance with values represented in results from the consumer survey: the majority of participants agree that TCA is important and should be implemented (cf. 3.4), and awareness-raising measures such as the 'True Prices' campaign were seen as interesting (cf. 3.2). The customers' and experts' feedback to the 'True Prices' campaign thus reflects the general perceived strength of TCA as an important tool to create consumer awareness for occurring socio-ecological damages and increased cost transparency (Lord 2020; Gemmill-Herren et al. 2021; Hendriks et al. 2021). Holistic accounting approaches which combine ecological, social, and animal welfare factors were especially favored (cf. 3.4): this integrative potential of TCA can be highlighted as perceived core strength and should thus, especially in case of utilizing true price calculations for informational means, be incorporated if possible.

While raised levels of awareness can already be seen as beneficial in motivating individual sustainable consumption behavior (especially with regard to trendsetters and pioneers of change; EO), environmental psychology shows that more is needed to effectively achieve changes and translate knowledge into action (Kollmuss \& Agyeman 2002; Stoll-Kleemann \& Schmidt 2017). Utilizing TCA as a tool to broaden the public's knowledge on external costs can be seen as a valuable aid in reaching citizen's acceptance for incorporating new climate and biodiversity policy instruments. However, it is crucial to point out that neither informational campaigns like this nor individual behavioral change in general, suffice as means to overcome the present institutional lock-ins and to sustainably transform agri-food-networks.

Yet, an actual implementation of TCA could help to achieve this transformation, aligning with the underlying economic assumption and literature, which demonstrates that an in- or decrease in food prices has an impact on consumption behavior (Andreyeva et al. 2010). With regard to 
the tardiness of action in the industrial and administrative sectors, triggering behavioral change might seem promising, and thus nudging through price adaptations can be seen as a powerful strategy in which TCA can influence lifestyle and dietary behavior: by actually introducing 'true prices', the knowledge-action gap would be targeted (cf. Andreyeva et al. 2010; Michalke et al. 2021). To avoid shortcomings regarding distributional social justice (c.f. 4.3) while actively reducing market distortions and establishing sustainable agri-food networks, an intelligent incorporation of TCA into existing framework conditions is pivotal. This would ensue actually targeting a change in production practices themselves by consequently tying the costs of occuring damages to the polluting actor.

Suitable structures for the implementation of the pricebased instrument of TCA within the spheres of taxonomy and lawmaking are adaptations of consumption taxes, $\mathrm{CO}_{2}$-Pricing, the proposed renewal for the European nonfinancial Reporting Directive (NFRD; European Commission 2021), and state-level laws on supply chain transparency and due diligence (EO, SI, TD). Another beneficial outlook would be a combined execution of TCA and a reformed agricultural subsidy practice, focusing on good practice in agriculture and downstream processes (SI). In the European Union, in particular, subsidies have a very large impact on the current and future agricultural industry. However, a large portion is paid as generalized area payments (currently approx. 70\%; European Commission 2021; Heinrich-Böll-Foundation 2019) and disregards special criteria of agricultural practice (such as organic produce or support in rural areas). Incorporating TCA could be the methodological centerpiece in a reformation of European subsidiary practice, creating veritable financial leverage towards encouraging meaningful, sustaining, and sustainable agriculture (SI).

\section{Embedding social justice in TCA frameworks}

Finally, the sensitive issue of social justice needs to be discussed in its multifaceted nature: nationwide aspects are, inequality amongst the different strata of consumers. Within the survey, many participants feared for their ability to pay for the 'true price', stating they could not afford it due to their low income (informal statements collected qualitatively). A socially just implementation of TCA is therefore crucial. If TCA was to be implemented with no differentiation on the receiving end of higher food prices, this would put even more pressure on already disadvantaged people with low incomes. On average, German households spend $10.8 \%$ of their monthly income on foodstuff (Bocksch 2020); participants of the survey, who reported lower net income, spend $16.17 \%$. This difference could be explained by the case study's focus on a discounter customer base, representing lower-income strata than the German average
(VuMA 2020). While an implementation of TCA is argued by research to be favorable regarding potentially reduced ecological costs (Gemmill-Herren et al. 2021; Bradshaw et al. 2021), it is important to address the issue of affordability. That true pricing will have a considerably greater effect on low-income strata is not just theoretically apparent, but also mirrored in customers' answers indicating that they would not have the economic means to choose freely between products.

Another important aspect for the general public's acceptance of TCA is that their moral values will not be taken advantage of for profit: it is paramount to emphasize once again that TCA must not be understood as a practice where solely the market prices for final consumers would rise; it is not conceptualized to merely lead to increasing consumer costs (SI). In its best manifestation, its methodological conception entails the Polluter Pays Principle and, where possible, the general avoidance of creating costs in the first place (Holden \& Jones, 2021). As expressed by customers and interviewed TCA practitioners alike, suitable areas for application of TCA up to now are mostly focusing on its communicational capacities. TCA is a tool to inform businesses and consumers about current states of supply chains and areas of possible improvement of socially and ecologically unjust practices.

A practical application of TCA is present in several pockets of the market (e.g. fair trade or eco labels). So far, this can be classified as voluntary payments by downstream supply chains and is receiving sustained interest by customers, practitioners, and TCA scholars alike, as this practical engagement in TCA provides valuable insights and potentially competitive advantage. However, it is important to emphasize that only a factual implementation of TCA into the main strata of the markets would create sufficient leverage on producers to change their practices and eventually achieve a sustainable transformation. A number of potential pathways for carrying this out in a socially just way are being discussed (cf. 3.5), with the common impediment of lacking governmental interest or action. Regardless of the described barriers for implementation, according to the experts, TCA has the potential to actually contribute to human and planetary wellbeing by unskewing present market distortions borne from unassessed externalities.

The summary of relevant potentials and obstacles of TCA implementation is shown in tab. 3 .

\section{Conclusion}

The general need for sustainable transformation is wellknown and is a scientific consensus (as shown in the most recent IPCC report). Agri-food networks are one essential aspect, as agricultural practices and foodstuff consumption 
have a high impact on emissions, land-use change, and biodiversity. While a change in production practices themselves is presumably a valid effect of TCA (and arguably the main function), this case study puts the focus on the consumers' perspective. The general public's acceptance is deemed crucial for a successful and socially supported implementation of TCA.

Rising awareness about externalities is observable within society and informational campaigns like the one discussed are met with positive feedback and can help raise this awareness. However, the 'True Prices' campaign evaluation demonstrates a persistent knowledge gap regarding ecological damages in foodstuff production. Therefore, further educational initiatives targeted at consumers and citizens are urgently necessary. Nevertheless, the survey results of the informational campaign have shown that the overwhelming majority of consumers would reduce animal products and increase organic products in their food consumption if prices rose through the implementation of TCA.

Following the results of the consumer survey, we also see limitations to a possible sustainable transformation: to reach societal acceptance of TCA, a socially just implementation is paramount. An unreflected and fast introduction would pose monetary constraints for customers and thus discourage consumption change according to their knowledge and ecological or social values. Nevertheless, responsibility for TCA implementation, and at the same time the costs of paying for arising ecological or social damages, cannot solely lie with the consumer, as individual consumption behavior is not significant in comparison to institutional unsustainability. A sustainable, ecologically and socially just turn in agri-food networks is rated (very) important by consumers and experts alike, mirroring the scientific consensus on a needed change in agricultural practice and consumption habits. Therefore, legislators must be held accountable to design a market that incentivizes holistically sustainable consumption, as well as production, without disregarding feasibility for the individual. Comprehensive compulsory adaptations by legislative powers are identified as necessary and socially anticipated, as long as they are formed in a transparent and just manner. Therefore, the biggest pitfall in implementing TCA would be an increase in consumer costs without generating change along the lines of production and economic value chains. This is in line with the expert feedback, which highlights the need for a sensible integration of TCA into legal and administrative frameworks.

TCA methods are also yet to be incorporated into conventional business' accounting as a transparency tool and competitive advantage that all businesses can or should access. Presently, a growing number of initiatives and networks working on and with TCA exist. To optimize consumers' confidence, TCA research has to work towards standardized calculation methods and develop useful tools ready for implementation. Those should facilitate a sensible level of preciseness without compromising on understandability and transparency. An implementation within existing agrifood networks necessitates transdisciplinary exchange and guidance between the economic sector, governments, and consumers.

TCA is in line with the mega-trend of sustainability. It encourages modern economic principles like the 'Economy for the common good' or the 'Doughnut Economy' and presents as one tool of many necessary to counteract the multidimensional crises that global society faces today. Valuable lessons can be learned from the experience gained within the existing TCA structures. Going further, i. a. a combination of different, mutually inclusive, economic and regulatory instruments seems promising. Research, inter-, and transdisciplinary work should be further extended to enable fulfilling the SDGs and national sustainability strategies.

Supplementary Information The online version contains supplementary material available at https://doi.org/10.1007/s11625-022-01105-2.

Funding Open Access funding enabled and organized by Projekt DEAL.

Open Access This article is licensed under a Creative Commons Attribution 4.0 International License, which permits use, sharing, adaptation, distribution and reproduction in any medium or format, as long as you give appropriate credit to the original author(s) and the source, provide a link to the Creative Commons licence, and indicate if changes were made. The images or other third party material in this article are included in the article's Creative Commons licence, unless indicated otherwise in a credit line to the material. If material is not included in the article's Creative Commons licence and your intended use is not permitted by statutory regulation or exceeds the permitted use, you will need to obtain permission directly from the copyright holder. To view a copy of this licence, visit http://creativecommons.org/licenses/by/4.0/.

\section{References}

Andreyeva T, Long MW, Brownell KD (2010) The impact of food prices on consumption: a systematic review of research on the price elasticity of demand for food. Am J Public Health 100:216222. https://doi.org/10.2105/AJPH.2008.151415

Baker L, Castilleja G, De Groot Ruiz A, Jones A (2020) Prospects for the true cost accounting of food systems. Nat Food 1:765-767. https://doi.org/10.1038/s43016-020-00193-6

Bandura A, Barbaranelli C, Caprara GV, Pastorelli C (1996) Mechanisms of moral disengagement in the exercise of moral agency. $\mathrm{J}$ Pers Soc Psychol 71:364

Barraque B (2003) Past and future sustainability of water policies in Europe. Nat Res Forum 27:200-211. https://doi.org/10.1111/ 1477-8947.00055

Baur N (2014) Handbuch Methoden der empirischen Sozialforschung, Bücher. Springer VS, Wiesbaden

Benka-Coker ML, Tadele W, Milano A, Getaneh D, Stokes H (2018) A case study of the ethanol CleanCook stove intervention and potential scale-up in Ethiopia. Energy Sustain Dev 46:53-64. https:// doi.org/10.1016/j.esd.2018.06.009 
Benton TG, Bieg C, Harwatt H, Pudasaini R, Wellesley L (2021) Food system impacts on biodiversity loss. Three levers for food system transformation in support of nature. Chatham House, London. https://action.ciwf.org/media/7443992/food-system-impacts-onbiodiversity-loss.pdf. Accessed 15 July 2021

Bilharz M (2000) Vom Wissen zum Handeln? Fallstricke und Chancen für die Umweltbildung. Servicestelle Bildung für eine nachhaltige Entwicklung in Umweltzentren. https://www.umweltbildung.de/ uploads/tx_anubfne/bilharz_wissen_handeln.pdf. Accessed 1 Nov 2021

Bobić J, Cvijetić S, Colić Barić I, Šatalić Z (2012) Personality traits, motivation and bone health in vegetarians. Coll Antropol $36: 795-800$

Bocksch R (2020) So viel geben EU-Haushalte für Essen und Trinken aus. https://de.statista.com/infografik/23239/anteil-von-nahru ngsmittel-und-getraenken-an-den-konsumausgaben/. Accessed 17 May 2021

Borden RJ, Francis JL (1978) Who cares about ecology? Personality and sex differences in environmental concern 1. J Pers 46:190-203

Bradshaw CJA, Ehrlich PR, Beattie A, Ceballos G, Crist E, Diamond J, Dirzo R, Ehrlich AH, Harte J, Harte ME, Pyke G, Raven PH, Ripple WJ, Saltré F, Turnbull C, Wackernagel M, Blumstein DT (2021) Underestimating the challenges of avoiding a ghastly future. Front Conserv Sci 1:615419. https://doi.org/10.3389/fcosc. 2020.615419

Campbell BM, Beare DJ, Bennett EM, Hall-Spencer JM, Ingram JSI, Jaramillo F, Ortiz R, Ramankutty N, Sayer JA, Shindell D (2017) Agriculture production as a major driver of the Earth system exceeding planetary boundaries. E\&S 22:art8. https://doi.org/10. 5751/ES-09595-220408

Centre for Research of the Epidemiology of Disasters (CRED) (2019) Natural Disasters 2018. An opportunity to prepare. https://www. cred.be/publications?page $=1$ Accessed 20 Aug 2021

Conijn JG, Bindraban PS, Schröder JJ, Jongschaap REE (2018) Can our global food system meet food demand within planetary boundaries? Agr Ecosyst Environ 251:244-256. https://doi.org/10.1016/j. agee.2017.06.001

de Adelhart Toorop R, Yates J, Watkins M, Bernard J, de Groot Ruiz A (2021) Methodologies for true cost accounting in the food sector. Nat Food 2:655-663. https://doi.org/10.1038/s43016-021-00364-z

Dietz T, Kalof L, Stern PC (2002) Gender, values, and environmentalism. Social Science Q 83:353-364. https://doi.org/10.1111/ 1540-6237.00088

Droste N, Hansjürgens B, Kuikman P, Otter N, Antikainen R, Leskinen P, Pitkänen K, Saikku L, Loiseau E, Thomsen M (2016) Steering innovations towards a green economy: understanding government intervention. J Clean Prod 135:426-434. https://doi.org/10.1016/j. jclepro.2016.06.123

Ekardt F (2015) Ökonomische Instrumente und Bewertungen der Biodiversität: Lehren für den Naturschutz aus dem Klimaschutz? Beiträge zur sozialwissenschaftlichen Nachhaltigkeitsforschung. Metropolis-Verlag, Marburg

European Commission (2021) Proposal for a DIRECTIVE OF THE EUROPEAN PARLIAMENT AND OF THE COUNCIL amending Directive 2013/34/EU, Directive 2004/109/EC, Directive 2006/43/EC and Regulation (EU) No 537/2014, as regards corporate sustainability reporting. https://eur-lex.europa.eu/legalcontent/EN/TXT/PDF/?uri=CELEX:52021PC0189\&from=EN. Accessed 12 July 2021

European Union (2008) Commission Regulation (EC) No 889/2008 of 5 September 2008 laying down detailed rules for the implementation of Council Regulation (EC) No 834/2007 on organic production and labelling of organic products with regard to organic production, labelling and control. https://www.bmel.de/Share dDocs/Downloads/DE/_Landwirtschaft/Biologischer-Landbau/ 889-2008-eg-durchfuehrungsbestimmungen.html. Accessed 12 July 2021

Federal Institute for Population research (2019) Average age of the population in Germany (1871-2019). URL: https://www.bib.bund. de/Permalink.html?id=10208850. Accessed 30 Jun 2021

Federal Statistical Office (2021a) Population by nationality and gender from 1970 to 2020 in Germany. URL: https://www.destatis.de/DE/ Themen/Gesellschaft-Umwelt/Bevoelkerung/Bevoelkerungsstand/ Tabellen/deutsche-nichtdeutsche-bevoelkerung-nach-geschlechtdeutschland.html;jsessionid=BB06AEBC1A252B2E9D4B9B890 720547F.live712\#fussnote-1-249820. Accessed 3 Dec 2021a

Federal Statistical Office (2021b). Population and employment. Households and families. Results of the microcensus. 2020 (first results). https://www.destatis.de/DE/Themen/Gesellschaft-Umwelt/Bevoe lkerung/Haushalte-Familien/Publikationen/Downloads-Haushalte/ haushalte-familien-2010300207004.pdf?_blob=publicationFile. Accessed 1 Dec 2021b

Federal Statistical Office (2021c) Income, consumption, living conditions and living costs. https://www.destatis.de/DE/Themen/Gesel lschaft-Umwelt/Einkommen-Konsum-Lebensbedingungen/Konsu mausgaben-Lebenshaltungskosten/Tabellen/pk-ngt-hhgr-evs.html. Accessed 20 July 2021c

Gaugler T, Stoeckl S, Rathgeber AW (2020) Global climate impacts of agriculture: A meta-regression analysis of food production. $\mathrm{J}$ Clean Prod 276:122575. https://doi.org/10.1016/j.jclepro.2020. 122575

Gemmill-Herren B, Baker LE, Daniels PA (eds) (2021) True cost accounting for food: balancing the scale. Series: Routledge studies in food, society and the environment, 1 st edn. Routledge, New York. https://doi.org/10.4324/9781003050803

German Federal Government (2021) German Sustainability Strategy 2021. https://www.bundesregierung.de/resource/blob/998006/ 1873516/3d3b15cd92d0261e7a0bcdc8f43b7839/2021-03-10dns-2021-finale-langfassung-nicht-barrierefrei-data.pdf?downl oad=1. Accessed 19 Aug 2021

Gerten D, Heck V, Jägermeyr J, Bodirsky BL, Fetzer I, Jalava M, Kummu M, Lucht W, Rockström J, Schaphoff S (2020) Feeding ten billion people is possible within four terrestrial planetary boundaries. Nat Sustain 3:200-208. https://doi.org/10.1038/ s41893-019-0465-1

Grunert KG, Brunsø K, Bredahl L, Bech AC (2001) Food-related lifestyle: a segmentation approach to European food consumers. In: Frewer LJ, Risvik E, Schifferstein H (eds) Food, people and society. Springer, Berlin, pp 211-230

Hansjürgens B (2015) Zur Neuen Ökonomie der Natur: Kritik und Gegenkritik. Wirtschaftsdienst 95:284-291. https://doi.org/10. 1007/s10273-015-1820-0

Heinrich-Böll-Foundation (2019) Agraratlas 2019, 3rd ed. https://www. boell.de/sites/default/files/2020-02/agraratlas2019_III_web.pdf? dimension1=ds_agraratlas_2019. Accessed 3 July 2021

Hendriks S, de Groot Ruiz A, Acosta MH, Baumers H, Galgani P, Mason-D'Croz D, Godde C, Waha K, Kanidou D, von Braun J (2021) The true cost and true price of food. Sci Innov 357. https:// www.researchgate.net/publication/355108393_The_true_cost_ and_true_price_of_food_A_paper_from_the_scientific_group_ of_the_UN_Food_Systems_Summit/citations Accessed: 1 Nov 2021

Hentschl M, Michalke A, Pieper M, Gaugler T, Stoll-Kleemann S (2021) Land use change and dietary transitions - Addressing preventable climate and biodiversity damage. Manuscript submitted for publication.

IPCC (2019) Global Warming of $1.5^{\circ} \mathrm{C}$. An IPCC Special Report on the impacts of global warming of $1.5^{\circ} \mathrm{C}$ above pre-industrial levels and related global greenhouse gas emission pathways, in the context of strengthening the global response to the threat of climate change, sustainable development, and efforts to eradicate poverty. 
IPCC (Intergovernmental Panel on Climate Change. https://www. ipcc.ch/site/assets/uploads/sites/2/2019/06/SR15_Full_Report_ High_Res.pdf Accessed 19 Aug 2021

Kelly NR, Mazzeo SE, Bean MK (2013) Systematic review of dietary interventions with college students: directions for future research and practice. J Nutr Educ Behav 45:304-313. https://doi.org/10. 1016/j.jneb.2012.10.012

Kennedy E, Webb P, Block S, Griffin T, Mozaffarian D, Kyte R (2021) Transforming food systems: the missing pieces needed to make them work. Curr Dev Nutr. https://doi.org/10.1093/cdn/nzaa177

Kollmuss A, Agyeman J (2002) Mind the Gap: why do people act environmentally and what are the barriers to pro-environmental behavior? Environ Educ Res 8:239-260. https://doi.org/10.1080/ 13504620220145401

Lord S (2020) Valuing the impact of food: towards practical and comparable monetary valuation of food system impacts. https://foodsivi.org/ wpcontent/uploads/2020/06/Valuing-the-impact-of-food-Report_ Foodsivi.pdf. Accessed 6 Dec 2021

Malek L, Umberger WJ, Goddard E (2019) Committed vs. uncommitted meat eaters: Understanding willingness to change protein consumption. Appetite 138:115-126. https://doi.org/10.1016/j.appet.2019. 03.024

Mayring P, Fenzl T (2014) Qualitative Inhaltsanalyse. In: Baur N, Blasius J (eds) Handbuch Methoden der empirischen Sozialforschung. Springer Fachmedien Wiesbaden, Wiesbaden, pp 543-556. https:// doi.org/10.1007/978-3-531-18939-0_38

Michalke A, Boldoczki S, Meßmann L, Thorenz A, Gaugler T, Tuma A (2021) Internalizing the environmental costs of organic and conventional food production on LCA midpoint level. Manuscript submitted for publication

Michalke et al. (2020) Abschlussbericht zum Forschungsprojekt How much is the dish? - True Cost Accounting von Umweltfolgekosten und „wahre Preisschilder“ in Deutschland. HoMaBiLe (How much is the dish?" - Measures for Increasing Biodiversity Through True Cost Accounting for Food Products). https://www.researchgate.net/ publication/346097024_True_Prices. Accessed 6 Aug 2021

OECD (1975) The Polluter Pays Principle. Paris.https://www.oecd-ilibr ary.org/docserver/9789264044845-en.pdf?expires $=1635841062 \&$ $\mathrm{id}=\mathrm{id} \&$ accname $=$ guest $\&$ checksum $=3$ B59AB3B3C545B07DC30 BBB865C5BFC6 Accessed 2 Nov 2021

Pieper M, Michalke A, Gaugler T (2020) Calculation of external climate costs for food highlights inadequate pricing of animal products. Nat Commun 11:6117. https://doi.org/10.1038/s41467-020-19474-6

Poore J, Nemecek T (2018) Reducing food's environmental impacts through producers and consumers. Science 360:987-992. https:// doi.org/10.1126/science.aaq0216

Pribis P, Pencak RC, Grajales T (2010) Beliefs and attitudes toward vegetarian lifestyle across generations. Nutrients 2:523-531. https://doi. org/10.3390/nu2050523

Rodi M (2010) The paradigm shift towards energy sustainability: climate change, innovation and the optimal instrument mix. In: Proceedings of the Summer Academy "Energy and the Environment", Greifswald, 20 July-8 August 2008. Lexxion, Berlin.

Sandhu H, Jones A, Holden P (2021) True Cost Accounting of Food Using Farm Level Metrics: A New Framework. Sustainability 13:5710. https://doi.org/10.3390/su13105710

Schwartz SH (1977) Normative influences on altruism. Adv Exp Soc Psychol 10:221-279

Springmann M, Mason-D'Croz D, Robinson S, Wiebe K, Godfray HCJ, Rayner M, Scarborough P (2017) Mitigation potential and global health impacts from emissions pricing of food commodities. Nat Clim Change 7:69-74. https://doi.org/10.1038/nclimate3155

Springmann M, Clark M, Mason-D'Croz D, Wiebe K, Bodirsky BL, Lassaletta L, de Vries W, Vermeulen SJ, Herrero M, Carlson KM, Jonell M, Troell M, DeClerck F, Gordon LJ, Zurayk R, Scarborough P, Rayner M, Loken B, Fanzo J, Godfray HCJ, Tilman D, Rockström
J, Willett W (2018) Options for keeping the food system within environmental limits. Nature 562:519-525. https://doi.org/10.1038/ s41586-018-0594-0

Stocké V (2014) Persönlich-mündliche Befragung. In: Baur N, Blasius J (eds) Handbuch Methoden der empirischen Sozialforschung. Springer Fachmedien Wiesbaden, Wiesbaden, pp 619-629. https:// doi.org/10.1007/978-3-531-18939-0_45

Stoll-Kleemann S, O'Riordan T (2015) The sustainability challenges of our meat and dairy diets. Environ Sci Policy Sustain Devt 57:34-48. https://doi.org/10.1080/00139157.2015.1025644

Stoll-Kleemann S, Schmidt UJ (2017) Reducing meat consumption in developed and transition countries to counter climate change and biodiversity loss: a review of influence factors. Reg Environ Change 17:1261-1277. https://doi.org/10.1007/s10113-016-1057-5

Sutton MA, Howard CM, Erisman JW, Billen G, Bleeker A, Grennfelt P, .Grizzetti B (eds) (2011) The European nitrogen assessment: sources, effects and policy perspectives. https://www.researchgate. net/profile/Jan-Willem-Erisman/publication/51997325_The_Europ ean_Nitrogen_Assessment_Sources_Effects_and_Policy_Perspectiv es/links/0fcfd50c612d07c556000000/The-European-Nitrogen-Asses sment-Sources-Effects-and-Policy-Perspectives.pdf. Accessed 4 Aug 2021

TEEB (2018) TEEB for Agriculture \& Food: Scientific and Economic Foundations. Geneva: UN Environment. http://teebweb.org/wpcontent/uploads/2018/11/Foundations_Report_Final_October.pdf. Accessed 26 Oct 2021

Tisdell CA (2005) Economics of environmental conservation. Edward Elgar Publishing

Umweltbundesamt (UBA) (2012) Best-Practice-Kostensätze für Luftschadstoffe, VerKehr, strom- und Wärmeerzeugung anhang B der ,,methodenkonvention 2.0 zur schätzung von umweltkosten“. https://www.umweltbundesamt.de/sites/default/files/medien/378/ publikationen/uba_methodenkonvention_2.0_-_anhang_b_0.pdf. Accessed 23 Nov 2021

Umweltbundesamt (UBA) (2019) Methodenkonvention 3.0 zur Ermittlung von Umweltkosten. Kostensätze. Stand 02/2019. Dessau Roßlau. https://www.umweltbundesamt.de/sites/default/files/ medien/1410/publikationen/2019-02-11_methodenkonvention-30_kostensaetze_korr.pdf. Accessed 4 Aug 2021

Umweltbundesamt (UBA) (2020) ProBas. Prozessorientierte Basisdaten für Umweltmanagementsysteme. Datenbank. https://www.probas. umweltbundesamt.de/php/index.php. Accessed 4 Aug 2021

United Nations (2015) Transforming our world: the 2030 Agenda for Sustainable Development. New York. https://www.un.org/ga/search/ view_doc.asp?symbol=A/RES/70/1\&Lang=E. Accessed 19 Aug 2021

United Nations (2019) Global sustainable development report 2019: the future is now-science for achieving sustainable development. New York. https://sustainabledevelopment.un.org/content/documents/ 24797GSDR_report_2019.pdf. Accessed 15 Aug 2021

Van Grinsven HJM, Holland M, Jacobsen BH, Klimont Z, Sutton MA, Jaap Willems W (2013) Costs and benefits of nitrogen for europe and implications for mitigation. Environ Sci Technol 47:3571-3579. https://doi.org/10.1021/es303804g

VuMA (2020) Penny-Kunden in Deutschland nach Netto-Einkommen im Vergleich mit der Bevölkerung im Jahr 2020 [Graph]. In Statista. https://de.statista.com/statistik/daten/studie/663318/umfrage/umfra ge-in-deutschland-zum-einkommen-von-penny-kunden/. Accessed: 14 Aug 2021

Weishaupt A, Ekardt F, Garske B, Stubenrauch J, Wieding J (2020) Land use, livestock, quantity governance, and economic instrumentssustainability beyond big livestock herds and fossil fuels. Sustainability 12:2053. https://doi.org/10.3390/su12052053

WRI (World Resources Institute) (2020) RELEASE: new data shows millions of people, trillions in property at risk from flooding-but infrastructure investments now can significantly lower flood risk. 
[WWW Document]. World Resource Institut. URL https://www. wri.org/news/2020/04/release-new-data-shows-millions-people-trill ions-property-risk-flooding-infrastructure. Accessed 1 Dec 2021

Yormirzoev M, Li T, Teuber R (2021) Consumers' willingness to pay for organic versus all-natural milk-does certification make a difference? Int J Consum Stud 45:1020-1029. https://doi.org/10.1111/ ijcs. 12622
Publisher's Note Springer Nature remains neutral with regard to jurisdictional claims in published maps and institutional affiliations. 